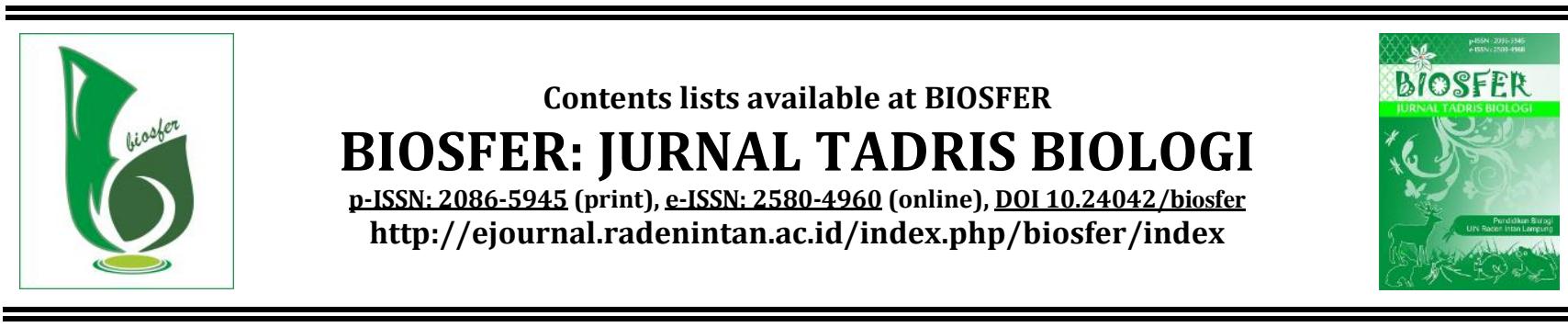

\title{
Environmentally Responsible Behavior and naturalist intelligence: Biology Learning to Support Sustainability
}

\author{
Rita Istiana ${ }^{*}$, Oding Sunardi², Fachrine Herlani ${ }^{3}$, Ilmi Zajuli Ichsan ${ }^{4}$, Danilo V. Rogayan Jr. ${ }^{5}$, \\ Md. Mehadi Rahman ${ }^{6}$, Mashudi Alamsyah ${ }^{7}$, Giry Marhento ${ }^{8}$, Ahmad Ali $^{9}$, WiwinPramita Arif ${ }^{10}$ \\ 1,2,3 Department of Biology Education, Universitas Pakuan, Indonesia \\ ${ }^{4}$ Department of Population and Environmental Education, Universitas Negeri Jakarta, Indonesia \\ ${ }^{5}$ Department of Natural Sciences, President Ramon Magsaysay State University, Philippines \\ 'Institute of Education and Research, University of Dhaka, Bangladesh \\ 7,8 Department of Biology Education, Universitas Indraprasta PGRI, Indonesia \\ 9,10 Department of Biology Education, UIN Alauddin Makassar, Indonesia
}

\section{ARTICLE INFO}

Article History

Received : 29-11-2020

Accepted : 19-12-2020

Published : 27-12-2020

Keywords:

Naturalist Intelligence;

Environmentally Responsible

Behavior;

Sequential Explanatory

*Correspondence email:

rita istiana@unpak.ac.id

ABSTRACT

Biology learning needs to support sustainable development. This research was a quantitative-qualitative sequential explanatory mixed research. This research aimed to obtain information about the relationship between naturalist intelligence and environmental responsibility behavior. This research was conducted in February-August 2019. The quantitative research data were obtained by using a questionnaire, and the qualitative research data were obtained by doing interviews and observations. The data hypothesis was tested using a correlation test with the Product Moment Pearson formula. The result of this research showed that there was a positive relationship between naturalist intelligence and environmentally responsible behavior with regress equation $\hat{Y}=20.331+0,7524 \mathrm{X}$, Correlation coefficient $(r)=0.66$, and determination coefficient $\left(r^{2}\right)=$ $43.56 \%$. it indicated that the interpretation value was strong. $r^{2}$ value means that $43.56 \%$ environmentally responsible behavior correlates by naturalist intelligence, and other factors influence $56.44 \%$ environmentally responsible behavior. Biology learning must provide innovations related to increasing students' knowledge about the environment. This study concludes that there is a correlation between the two variables.
\end{abstract}

\section{Perilaku Bertanggung Jawab Terhadap Lingkungan dan Kecerdasan Naturalis: Pembelajaran Biologi untuk Mendukung Keberlanjutan}

\footnotetext{
Abstrak: Pembelajaran Biologi harus bisa memiliki peran untuk mendukung pembangunan berkelanjutan. Penelitian ini merupakan penelitian kombinasi Sequential Explanatory kuantitatif-kualitatif. Penelitian ini bertujuan untuk mendapatkan informasi mengenai hubungan antara kecerdasan naturalis dengan perilaku tanggung jawab lingkungan. Penelitian ini dilaksanankan pada bulan Februari - Agustus 2019. Data penelitian kuantitatif diperoleh menggunakan kuisioner dan data penelitian kualitatif diperoleh menggunakan wawancara dan observasi. Analisis data kualitatif dengan reduksi data,
} 
Biosfer, 11 (2) (2020) 87 - 100

Rita Istiana, Oding Sunardi, Fachrine Herlani, Ilmi Zajuli Ichsan, Danilo V. Rogayan Jr., Md. Mehadi

Rahman, Mashudi Alamsyah, Giry Marhento, Ahmad Ali, Wiwin Pramita Arif

penyajian data, dan penarikan kesimpulan. Pengujian hipotesis data menggunakan uji korelasi dengan rumus ProductMoment Pearson. Hasil penelitian menunjukkan bahwa terdapat hubungan positif antara kecerdasan naturalis dengan perilaku tanggung jawab lingkungan dengan persamaan regresi $\hat{Y}=20,331+0,7524 X$. Nilai koefisien korelasi $(r)=0,66$ dan koefisien determinasi $\left(r^{2}\right)=43,56 \%$ dengan nilai interpretasinya kuat. Nilai $r^{2}$ mengandung arti bahwa 43,56\% perilaku tanggung jawab lingkungan berhubungan oleh kecerdasan naturalis dan 56,44\% dipengaruhi oleh faktor lain. Pembelajaran Biologi harus memiliki peran untuk bisa memberikan inovasi terkait dengan peningkatan pengetahuan siswa tentang lingkungan. Kesimpulan dari penelitian ini adalah bahwa terdapat korelasi antara kedua variabel tersebut.

\section{INTRODUCTION}

The environment is everything surrounding human beings, which is comprised of both biotic and abiotic factors. The environment and humans are interdependent. The environment affects human life development; thus, humans cannot survive and thrive without the environment (Chouhan et al., 2017; Siriwardena et al., 2013).

The environment provides a multitude of benefits for human survival. It provides human necessities, including basic resources, such as clothing, food, and shelter. It is a vital interaction tool between humans and between humans and other organisms. Moreover, the environment produces energy sources and minerals to support human life.

Environment quality is one of the most important components of life quality (Keles, 2012). The environment has benefits for human survival. It provides human necessities as basic resources, such as clothing, food, and shelter. It is useful as an interaction tool between humans and between humans and other organisms. It produces energy sources and minerals to support human life.

Environment quality increasingly decreases over the years. Natural sources, like earthquakes, floods, etc., and human sources, such as accidents caused by industries, traffic, municipal facilities, and fires, are causing environmental degradation
(Keles, 2012). It indicates that the environment experiences damage every year. The environmental damage brings negative impacts on the survival of humans and other living things. The negative impacts include global warming that will affect climate change and disruption in environmental balance that, in turn, will reduce the number of animal and plant species or even bring them to extinction and disturb the health of living things, especially humans. Environmental degradation triggers a decrease in health quality that indirectly reduces human resource quality since health is a factor of human resource quality.

One of the causes of environmental damage is humans who are less responsible for the environment. To date, humans often use their right to utilize the environment and tend to be exploitative instead of performing their duties to be responsible for the environment. The earth is now suffering from innumerable afflictions caused by egregious human activities that are relentlessly denuding the environment (Rogayan Jr, 2019).

Previous research has been carried out about various efforts to develop learning environments. One of them is developing various technology-based learning media (Boholano, 2017; Grosch et al., 2014; Reyna et al., 2018). Various social media have also been developed to improve environmental learning (Al-Rahmi \& Zeki, 2017; Cheng et al., 2017). Also, various surveys were carried 


\section{Biosfer, 11 (2) (2020) 87 - 100}

Rita Istiana, Oding Sunardi, Fachrine Herlani, Ilmi Zajuli Ichsan, Danilo V. Rogayan Jr., Md. Mehadi Rahman, Mashudi Alamsyah, Giry Marhento, Ahmad Ali, Wiwin Pramita Arif

out related to students' abilities to solve problems around them (Saputro et al., 2019; Smith, 2014). Various studies have also been conducted related to efforts to improve students' and society's environmentally friendly behavior in general (Sugandini et al., 2018).

The environmental damage and degradation could be minimized if humans carry out their responsibility for the environment. Humans must have responsible behavior towards the environment to prevent environmental damage and other living things' survival. People's awareness has been recognized as a powerful environmental sphere tool (Rogayan Jr \& Nebrida, 2019).

He et al. (2018) express that environmentally responsible behavior tries to preserve the environment and look for environmental issues. It is in line with Oluyinka's (2011) statement that environmentally responsible behavior is individual or group acts aimed at doing the right thing to protect the environment in daily life, such as recycling, energy conservation, or reduction of littering and uncaring towards the environment. According to Thapa (2010), environmentally responsible behavior contains several dimensions: recycling, avoiding purchasing to minimize environmental impacts as a form of green consumerism, becoming politically active in a community to influence decisions that have an impact on the environment, and self-educating on environmental awareness.

Goyal (2017) opines that environmentally responsible behavior is a measure of someone's readiness to be active in protecting the environment. It was similar to a statement by Su et al. (2018) that it is a mechanism of environmental protection to reduce and avert environmental resource destruction.

Environmentally responsible behavior is one's or a group of people's reaction and action who search and implement solutions to maintain good environmental conditions or improve and minimize environmental problems. It could be improved through education. One effort to improve it is by enhancing students' naturalist intelligence.

Mauladin (2013) states that naturalist intelligence is an intelligence and skill to observe a pattern in nature and understand the natural system and human-made systems. Juniarti (2015) argues that naturalist intelligence can recognize, differentiate, utter, and categorize those related to flora, fauna, and the surrounding natural objects. Biology learning plays a role in supporting the enhancement of students' naturalist intelligence. It is due to the biology learning objects related to the organism or living things (Saputri et al., 2019; Veselinovska et al., 2011). This carries out to support sustainable development efforts.

Naturalist intelligence is someone's skill to recognize, understand, and categorize components in nature and interest in observing natural components and care for the environment. It can be improved through education. An intelligence can influence behavior as indicated by (Wahyuni et al., 2016).

This research aims to generate information on the relationship between naturalist intelligence and environmentally responsible behavior and identify other factors influencing students' environmentally responsible behavior in Grade X MIPA at MANs in Bogor.

\section{METHOD}

The research was carried out at MAN 1 and MAN 2 Bogor in semester 1 of the academic year of 2019/2020. The research started from July to August 2019. The research method was a sequential explanatory mixed method. The research variables consisted of an independent variable $(\mathrm{X})$ of naturalist intelligence and a 
dependent variable (Y) of environmentally responsible behavior.

The research population included all Grade XI MIPA students in Bogor, namely MAN 1 and MAN 2, consisting of 438 students. Sampling conducted using proportional random sampling with Slovin's criteria and resulted in 209 students for samples.

The instrument employed to measure the relationship between naturalist intelligence and environmentally responsible behavior was a questionnaire. The questionnaire used a Likert Scale that contained some positive and negative statements with 5 (five) response choices.

Validity test to both instruments carried out by testing each question item using the Pearson Product Moment formula. The testing criteria were determined by comparing $r_{\text {value }}$ to $r_{\text {statistic }}$. If the $r_{\text {value }}$ is greater than $r_{\text {statistic }}\left(r_{\text {value }}>r_{\text {statistic }}\right)$ in a confidence level of $(\alpha=0.05)$, then the instrument is valid. Of the 40 questions in the naturalist intelligence $(X)$ instrument, 30 questions were valid. As regards the environmentally responsible behavior of the 40 questions tested, 31 questions were valid.

A reliability test was conducted after the validity test for both instruments using Cronbach's Alpha technique. If the coefficient of reliability is equal to or greater than 0.70 , then it is reliable. Based on the calculation, the question items' reliability value in the naturalist intelligence instrument was 0.89, whereas the environmentally responsible behavior instrument was 0.9 .

Data collected were analyzed using descriptive statistics and inferential statistics. A normality test of estimated standard error was carried out to test the data normality using the Liliefors test. The data homogeneity test used the Bartlett test to determine the data homogeneity. If data were normally distributed and homogeneous, then parametric statistics were used to analyze data. The hypothesis testing was conducted using the simple regression correlation technique of the Pearson product-moment correlation. It aimed to identify the magnitude of the relationship between naturalist intelligence and environmentally responsible behavior. The correlation significance test was carried out using a t-test at $\alpha=0.05$.

The correlation analysis would test the following hypotheses:

$H_{0}: \rho x y \leq 0$, there is no positive relationship between naturalist intelligence and environmentally responsible behavior of students in Grade X MIPA at MANs in Bogor.

$H_{a}: \rho x y>0$, there is a positive relationship between naturalist intelligence and environmentally responsible behavior of students in Grade X MIPA at MANs in Bogor.

The above research concept could be defined as a relationship between naturalist intelligence and environmentally responsible behavior. The research subfocus obtained after the quantitative research was completed.

Data generated in the research were originated from primary data of written as well as unwritten data. The data were direct data provided to the researchers from an interview. The researchers selected the research informants.

The data collection procedures in the research were observation and interview, and the interview results were recorded. The recording results were recorded in the form of written notes. The data analysis technique used was qualitative data analysis that consisted of data reduction, data presentation, and conclusion drawing activities.

The data from the hypothesis testing results using the quantitative method were combined with the qualitative method's 
data. Therefore, the quantitative data will be expanded and deepened with the qualitative data.

\section{RESULTS AND DISCUSSION}

Data of the research results that will be presented consisted of data from the quantitative research result (description of research result data, two data prerequisite testing of normality and homogeneity tests, and submission of hypotheses) and data from the qualitative research results (data reduction, data presentation, and conclusion drawing)

The two variables were measured using a questionnaire with a Likert Scale. The research results in the environmentally responsible behavior variable (Y) derived a mean value of 101.44 ; median of 103 ; modus of 112; the standard deviation of 11.01; variance of a sample of 121.25; a range of 57; a maximum score of 126; minimum score of 69; total score of 21202; a number of the respondent of 209; the number of class of 9; and class length of 7. The research results in naturalist intelligence variable $(\mathrm{X})$ derived mean value of 107.81; median of 108; modus of 112; the standard deviation of 9.63 ; variance of a sample of 92.80; a range of 40; a maximum score of 124 ; minimum score of 84 ; total score of 22532; a number of the respondent of 209; several class of 9; and class length of 5.

The analysis prerequisite test employed normality and homogeneity tests. The normality test of estimated standard error $Y-\hat{Y}$ used the Liliefors test. The normality calculation resulted Liliefors value $\left(L_{o}\right)$ of 0.056 with $\mathrm{N}=209$ and significance level of $\alpha=0.05$ the $L_{t}=0.0596$; thus $L_{o}<$ $L_{t}$ or $0.056115<0.0596$. It can be inferred that the estimated standard error between environmentally responsible behavior and naturalist intelligence came from a normally distributed population. The homogeneity test calculation applied the Bartlett test. The test was carried out by comparing $\chi_{\text {value }}^{2}$ with $\chi_{\text {statistic }}^{2}$. If the value of $\chi_{\text {value }}^{2}<\chi_{\text {statistic }}^{2}$ statistic, both variables' variance is homogeneous and vice versa. Calculation results indicated $\chi \chi_{\text {value }}^{2}=44.0098$, and the chi-square table obtained db. $=40-1=39$ in a significance level $\alpha=0.05$; hence, $\chi_{\text {statistic }}^{2}=$ 54.57. It can be interpreted that the data variance of environmentally responsible behavior and naturalist intelligence originated from a homogenous population.

Two hypotheses would be tested in the research via a statistical method of regression and correlation tests. Two data would be tested, namely: environmentally responsible and naturalist intelligence. The data had been stated as normal and homogeneous; thus, hypothesis testing could follow. The hypothesis testing aimed to determine whether the proposed null hypothesis $\left(H_{0}\right)$ can be accepted or vice versa, in a significance level $\alpha=0.05$. The hypotheses were $H_{1}: \rho x y>0, H_{1}: \rho x y \leq 0$.

The regression test was carried out to learn the functional relationship between variable $X$ (naturalist intelligence) and variable $Y$ (environmentally responsible behavior). The results of statistical calculations obtained a regression equation $\hat{\mathrm{Y}}=20.331+0.7524 X$. It suggested that the simple linear regression resulted in a regression direction of $0.7524 \mathrm{X}$ in the same direction as a constant of 20.331 .

The regression equation can be interpreted that the students already held environmentally responsible behavior before having the naturalist intelligence constant of 20.331. Every increase of one unit in the naturalist intelligence value increases the environmentally responsible behavior of 0.7524 . The regression equation is graphically illustrated in Figure 1. 
Biosfer, 11 (2) (2020) 87 - 100

Rita Istiana, Oding Sunardi, Fachrine Herlani, Ilmi Zajuli Ichsan, Danilo V. Rogayan Jr., Md. Mehadi

Rahman, Mashudi Alamsyah, Giry Marhento, Ahmad Ali, Wiwin Pramita Arif

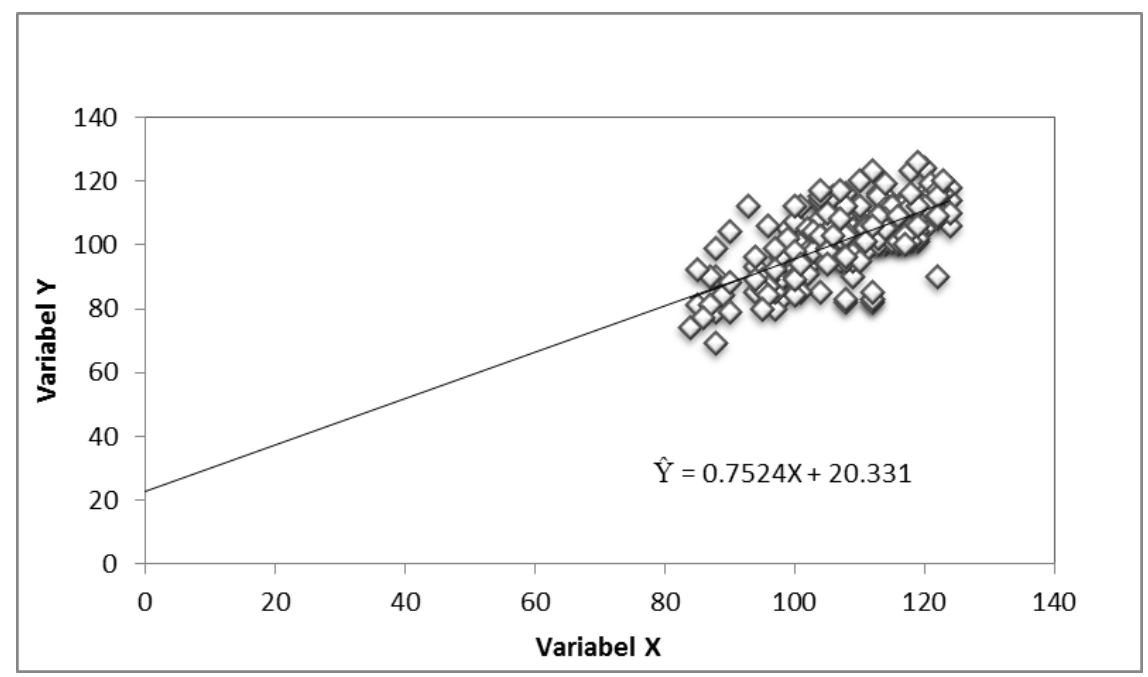

Figure 1. Regression Line of Relationship between Naturalist Intelligence (X) and Environmentally Responsible Behavior

The regression linearity test was intended to discover whether the regression model used is linear or vice versa. The regression significance test was carried out to find out the significance of the regression equation obtained. The results of the linearity test and regression significance test can be seen in Table 1 .

Table 1. ANOVA for Significance Test and Linearity Test with Regression Equation

$$
\hat{\mathrm{Y}}=20.331+0.7524 \mathrm{X}
$$

\begin{tabular}{|c|c|c|c|c|c|c|c|}
\hline \multirow{2}{*}{$\begin{array}{l}\text { Source of } \\
\text { Variance }\end{array}$} & \multirow{2}{*}{ dK } & \multirow{2}{*}{ JK } & \multirow{2}{*}{ KT } & \multirow{2}{*}{$\mathbf{F}$} & \multicolumn{2}{|c|}{$F_{\text {total }}$} & \multirow{2}{*}{ Description } \\
\hline & & & & & 0.05 & 0.01 & \\
\hline Total & 209 & 2176056 & 10411.8 & - & - & - & - \\
\hline Coefficient a & 1 & 2150836 & 2150836 & \multirow{3}{*}{157.37} & \multirow{3}{*}{3.87} & \multirow{3}{*}{6.76} & \multirow{3}{*}{ Significance } \\
\hline $\operatorname{Reg}(b / a)$ & 1 & 10892.1 & 10892.1 & & & & \\
\hline Residuals & 207 & 14327.5 & 69.2151 & & & & \\
\hline Lack of fit & 38 & 3377.41 & 88.8793 & \multirow[t]{2}{*}{1.37} & \multirow[t]{2}{*}{1.48} & \multirow[t]{2}{*}{1.73} & \multirow[t]{2}{*}{ Linear } \\
\hline Error & 169 & 10950.1 & 64.7935 & & & & \\
\hline
\end{tabular}

Where:

$\mathrm{dK}=$ Degree of freedom

$\mathrm{JK}=$ Sum of square

KT $=$ Total square

Table 1 indicates that the regression significance calculation obtained $F_{\text {value }}$ of $157.37>F_{\text {statistic }}$ of 3.87 with significance level $\alpha=0,05$. It can be inferred that the regression equation of naturalist intelligence (X) with environmentally responsible behavior (Y) was significant. In contrast, the linearity test resulted in $F_{\text {value }}$ of $1.37>F_{\text {statistic }}$ of 1.48 , indicating that the regression model was linear. Based on the significance test and linearity test, it can be concluded that the simple regression 
Rita Istiana, Oding Sunardi, Fachrine Herlani, Ilmi Zajuli Ichsan, Danilo V. Rogayan Jr., Md. Mehadi Rahman, Mashudi Alamsyah, Giry Marhento, Ahmad Ali, Wiwin Pramita Arif

analysis with equation $\hat{Y}=20.331+$ $0.7524 X$ was significant and linear.

The correlation test carried out using Pearson's product-moment formula. The calculation derived coefficient of correlation between naturalist intelligence and environmentally responsible behavior of 0.66. The correlation significance test employed a t-test. The results of the correlation calculation and correlation significance test are presented in Table 2.

Table 2. The Summary of t-test Correlation Calculation Results

\begin{tabular}{|c|c|c|c|c|c|c|}
\hline \multirow{2}{*}{$\mathbf{N}$} & \multirow{2}{*}{$\begin{array}{l}\text { Coefficient of } \\
\text { Correlation (r) }\end{array}$} & \multirow{2}{*}{$\begin{array}{c}\text { Coefficient of } \\
\text { Determination }\left(r^{2}\right)\end{array}$} & \multirow{2}{*}{ t-value } & \multicolumn{2}{|c|}{ Significance } & \multirow{2}{*}{ Description } \\
\hline & & & & $1 \%$ & $5 \%$ & \\
\hline 209 & 0.66 & $43.56 \%$ & 16.82 & 2.6 & 2 & $\begin{array}{c}\mathrm{H} 0 \\
\text { is rejected }\end{array}$ \\
\hline
\end{tabular}

The calculation results of the t-test correlation indicate that the coefficient of correlation was positive with $r=0.66$, and the coefficient of determination was $43.56 \%$. The calculation of significance of correlation value gained $t_{\text {value }}=16.82$, whereas $t_{\text {statistic }}$ for significance level $\alpha=0.05$ was 2 and 2.6 for significance level $\alpha=0.01$. The calculation results indicated that $t_{\text {value }}>$ $t_{\text {statistic }}$, thus the correlation was significant. It implied a strong positive relationship between naturalist intelligence $(\mathrm{X})$ and environmentally responsible behavior (Y). The strong relationship or correlation was indicated by the correlation coefficient value (r) ranging between 0.60 and 0.799 .

The qualitative research was carried out after the quantitative research results were obtained. The result showed that, based on observation, many students are still littering everywhere. Also, there are still various environmental conditions that are less well maintained. This showed that the implementation of student behavior had not been carried out as expected. Also, the results of observations indicate that not many environmental learning media are based on 21st-century abilities. This will certainly make it difficult for students to participate in various activities in solving environmental problems. In addition to the observation results, it will be discussed for each sub-focus.
The formulation of sub-focuses in the research was adjusted to the quantitative research results previously derived. The quantitative research had a correlation coefficient value between naturalist intelligence and environmentally responsible behavior of 0.66 and a determination coefficient value of $43.56 \%$. The correlation coefficient value signified a strong relationship; thus, the research subfocuses will strengthen the high relationship between naturalist intelligence and environmentally responsible behavior and other factors that were deemed to have a relationship with the environmentally responsible behavior. The research finding was based on data and information from each research sub-focus.

Conclusion of Sub-Focus 1, naturalist intelligence had a strong relationship with environmentally responsible behavior since students who have naturalist intelligence understand the natural conditions, such as the surrounding environmental condition including animals and plants, recognize the impacts of the deteriorated environment, fond of nature, sensitive to natural conditions, and care towards the environment. This induces the students who have naturalist intelligence to know what they must do to nature as they cognize the consequences of being irresponsible towards the environment. The naturalist 


\section{Biosfer, 11 (2) (2020) 87 - 100}

Rita Istiana, Oding Sunardi, Fachrine Herlani, Ilmi Zajuli Ichsan, Danilo V. Rogayan Jr., Md. Mehadi Rahman, Mashudi Alamsyah, Giry Marhento, Ahmad Ali, Wiwin Pramita Arif

intelligence will guide them to have environmentally responsible behavior in their environment. Naturalist intelligence was important in learning science (Samsudin et al., 2015). Students who hold naturalist intelligence will have instinct, awareness, and reflexes responsible for the environment. Naturalist intelligence could be formed by education by parents or teachers who teach the students to love nature. It can increase with age as it acquires from the students' sciences; therefore, they understand nature's condition. This can be a character reflected from habits and behaviors to be responsible for the natural environment. The schools' role is vital to developing environmentally-aware and ecologically-conscious students (Rogayan Jr \& Nebrida, 2019).

Conclusion of Sub-Focus 2, factors related to environmentally responsible behavior consisted of family, school environment, friendship, information, policy, and self. Students who are educated to be responsible for the environment since childhood will grow to be a person with good, environmentally responsible behavior as it has become their habit. Children's

awareness of the environment and active participation in conserving the environment can be considered a further aspect of pro-social behavior (Honig \& Mennerich, 2012). Teachers who guide students to be responsible for the environment will make students be one. School activities, such as extracurricular environment and adventure activity, scout, and youth scientific group, affect students' behavior to be responsible for the environment. Students who have environmentally responsible friends will behave the same. This behavior can change other community components to keep their environment (Bronfman et al., 2015; Takahashi \& Selfa, 2015).

This also applies to their neighborhood; they will become familiar with conducting responsible things for the environment if they are often involved in such activities in their neighborhood. Students could acquire information about the environment through school subjects, such as Biology and religion, and social media.

Teachers could remind and guide students on the importance of being responsible for the environment via school subjects; hence, students know environmental responsibility. Students often search for information through social media on their mobile phones. This media was based on technology to improve learning (Huang et al., 2010; Moghavvemi et al., 2018; Nugraini et al., 2013). Consequently, the information obtained affects their environmentally responsible behavior. Students who are irresponsible for the environment will receive reprimand and punishment with a deterrent effect; therefore, students will be more responsible for the environment. Students demand a comfortable environment, and they will earn it if they are responsible for the environment.

Derived from the research results, naturalist intelligence had a positive relationship with environmentally responsible behavior. Students who acquire high naturalist intelligence will have good, environmentally responsible behavior. Every increase of one value unit of naturalist intelligence will increase environmentally responsible behavior by 0.7524 . Naturalist intelligence impacted environmentally responsible behavior of $43.56 \%$, whilst other factors influenced $56.44 \%$ of the environmentally responsible behavior.

Students who possess naturalist intelligence will grasp the condition of nature. For example, they will recognize the environmental condition and the impacts of the deteriorated environment. They will fond of nature, sensitive to the natural conditions, and care towards the 
environment. It triggers the students to understand what to do to nature as they realize the consequences of nature's negative actions. Many concepts in an environment that must be solved by the student to protect their environment. Especially the problem of waste and much pollution (Chander \& Muthukrishnan, 2015; X He \& Liu, 2018).

Students with high naturalist intelligence will have environmental knowledge that shapes their belief that they have good, environmentally responsible behavior. This will be a character reflected from habits and behaviors to be responsible for the environment. The character will be shaped through repetitive behavior (Goldman et al., 2017; Qian et al., 2019; Shabani et al., 2013).

Factor related to environmentally responsible behavior is family. Family parenting is vital in the establishment of children's behavior. Parenting style to children, such as good communication and support of the children, will bring effect and positive behavior in children (Asmuni et al., 2012; Hacieminoglu, 2016). The parenting style influences the formation of the child's personality as an adult, for it is embedded since childhood(Puech et al., 2019). Parental guidance is consequential as parents are the builder of the children's foundation and character (McLean et al., 2017). Students who are educated to be responsible for the environment since childhood will grow to be responsible for environmentally responsible behavior (Evans et al., 2018; Janmaimool \& Khajohnmanee, 2018).

The second factor that had a relationship with environmentally responsible behavior was the school environment. Teachers could assist students in improving their attitudes and behaviors. A close relationship between teachers and students has benefits, such as developing students' positive behavior (Purwanto et al., 2020; Sigit et al., 2020). Teachers who guide students to be responsible for the environment will make students be one. School activities, such as extracurricular environment and adventure activity, scout, and youth scientific group, affect students' behavior. These activities will train students to be responsible for the environment (Sigit et al., 2019, 2020).

The third factor related to environmentally responsible behavior was information. Students could acquire information about the environment through school subjects as well as from social media. Teachers can educate students via school subjects to know the environment and the account of environmentally responsible behavior. A teacher should instill good behaviors to become the students' characters (Miarsyah et al., 2019). Knowledge will engender a feeling that triggers the urge to act (Ichsan et al., 2019; Ichsan \& Rahmayanti, 2020). Education will affect an ability to digest information received and consider the information as a basis for subsequent behavior (Avan et al., 2011; Leong et al., 2016). It is not likely for someone to consciously care about the environment if he/she knows nothing about the environment and positive actions towards the environment. High knowledge of environmental issues affects someone's useful decision-making (Rahmayanti et al., 2020). Students who possess environmental knowledge will have positive behavior towards the environment.

Science ideas can help raise environmental awareness because science teachers must ensure that students can share their knowledge, skills, and ideas in the classroom (Rahman, 2018). Therefore, Biology education plays a role to be able to provide various environmental concepts to students. Biology learning in class should be provided with a direction to studentcentered. This will encourage students to be more active in conducting environmentalthemes biology learning. The teaching materials provided are those related to 
Rita Istiana, Oding Sunardi, Fachrine Herlani, Ilmi Zajuli Ichsan, Danilo V. Rogayan Jr., Md. Mehadi Rahman, Mashudi Alamsyah, Giry Marhento, Ahmad Ali, Wiwin Pramita Arif

various environmental concepts teachable using various media, such as android-based media (Ichsan et al., 2020; Miarsyah et al., 2019). Various efforts are taken to support sustainable development so that future generations can still enjoy environmental sustainability. The people should learn to translate environmental degradation to environmental stewardship, leading to life preservation (Rogayan Jr, 2019).

\section{CONCLUSIONS AND SUGGESTIONS}

Referring to the research results, it can be inferred that there was a positive relationship between naturalist intelligence and environmentally responsible behavior of students in Grade XI MIPA at MANs in Bogor. The positive relationship was indicated by regression equation $\hat{Y}=20.331$ $+0.7524 \mathrm{X}$ with coefficient of correlation $(\mathrm{r}$ ) $=0.66$ and coefficient of determination $\left(\mathrm{r}^{2}\right)=$ $43.56 \%$. This suggested that the correlation coefficient value was significant and had a strong interpretation. Efforts to improve students' abilities could be carried out through various innovations in biology learning media.

\section{REFERENCES}

Al-Rahmi, W. M., \& Zeki, A. M. (2017). A model of using social media for collaborative learning to enhance learners' performance on learning. Journal of King Saud University Computer and Information Sciences, 29(4), 526-535. https://doi.org/10.1016/j.jksuci.2016.0 9.002

Asmuni, S., Khalili, J. M., \& Zain, Z. M. (2012). Sustainable Consumption Practices of Students in an Urban Setting: A Case in Selangor. Procedia - Social and Behavioral Sciences, 36(June 2011), 716-722.

https://doi.org/10.1016/j.sbspro.2012.

\subsection{8}

Avan, C., Aydinli, B., Bakar, F., \& Alboga, Y. (2011). Preparing Attitude Scale to Define Students' Attitudes about Environment, Recycling, Plastic and Plastic Waste. International Electronic Journal of Environmental Education, 1(3), 179-191. https://dergipark.org.tr/en/pub/iejeeg reen/issue/7905/104039

Boholano, H. B. (2017). Smart social networking: 21st century teaching and learning skills. Research in Pedagogy, 7(1), 21-29. https://doi.org/10.17810/2015.45

Bronfman, N. C., Cisternas, P. C., LópezVázquez, E., De la Maza, C., \& Oyanedel, J. C. (2015). Understanding attitudes and pro-environmental behaviors in a chilean community. Sustainability, 7(10), 14133-14152. https://doi.org/10.3390/su71014133

Chander, P., \& Muthukrishnan, S. (2015). Green consumerism and pollution control. Journal of Economic Behavior and Organization, 114, 27-35. https://doi.org/10.1016/j.jebo.2015.02 .013

Cheng, M., Wong, I. K. A., Wearing, S., \& McDonald, M. (2017). Ecotourism social media initiatives in China. Journal of Sustainable Tourism, 25(3), 416-432. https://doi.org/10.1080/09669582.20 16.1214141

Chouhan, S., Bhatnagar, B., Suman, \& Kaur, M. (2017). Assessment of Environmental Attitude of Adolescent of Bikaner City. Studies on Home and Community Science, 11(1), 25-28. https://doi.org/10.1080/09737189.20 17.1336308

Evans, G. W., Otto, S., \& Kaiser, F. G. (2018). 
Biosfer, 11 (2) (2020) 87 - 100

Rita Istiana, Oding Sunardi, Fachrine Herlani, Ilmi Zajuli Ichsan, Danilo V. Rogayan Jr., Md. Mehadi Rahman, Mashudi Alamsyah, Giry Marhento, Ahmad Ali, Wiwin Pramita Arif

Childhood Origins of Young Adult Environmental Behavior. Psychological Science, 29(5), 679-687. https://doi.org/10.1177/09567976177 41894

Goldman, D., Pe'er, S., \& Yavetz, B. (2017). Environmental literacy of youth movement members-is environmentalism a component of their social activism? Environmental Education Research, 23(4), 486-514. https://doi.org/10.1080/13504622.20 15.1108390

Goyal, S. (2017). Developing Responsible Environmental Behaviour in Indian Adolescents: An Experimental Study. Education Quest: An Int. J. of Education and Apllied Social Science, 8(2), 431441. https://doi.org/10.5958/22307311.2017.00120.9

Grosch, M., Berger, R., Gidion, G., \& Romeo, M. (2014). Which media services do students use in fact? Results of an international empirical survey. Procedia - Social and Behavioral Sciences, 141, 795-806.

https://doi.org/10.1016/j.sbspro.2014. 05.139

Hacieminoglu, E. (2016). Elementary school students' attitude toward science and related variables. International Journal of Environmental and Science Education, 11(2), 35-52. https://doi.org/10.12973/ijese.2016.2 $88 \mathrm{a}$

He, X, \& Liu, Y. (2018). The public environmental awareness and the air pollution effect in Chinese stock market. Journal of Cleaner Production, 185, 446454.

https://doi.org/10.1016/j.jclepro.2018. 02.294

He, Xuehuan, Hu, D., Swanson, S. R., Su, L., \&
Chen, X. (2018). Destination Perceptions, Relationship Quality, and Tourist Environmentally Responsible Behavior. Tourism Management Perspectives, 28(August), 93-104. https://doi.org/10.1016/j.tmp.2018.08. 001

Honig, A. S., \& Mennerich, M. (2012). What does 'Go Green' mean to children? Early Child Development and Care, 183(2), 171-184.

Huang, Y. C., Backman, S. J., \& Backman, K. F. (2010). Student attitude toward virtual learning in second life: A flow theory approach. Journal of Teaching in Travel and Tourism, 10(4), 312-334. https://doi.org/10.1080/15313220.20 10.525425

Ichsan, I. Z., \& Rahmayanti, H. (2020). HOTSEP: Revised Anderson's Taxonomy in environmental learning of COVID-19. European Journal of Educational Research, 9(3), 1257-1265. https://doi.org/10.12973/eujer.9.3.1257

Ichsan, I. Z., Sigit, D. V., Miarsyah, M., Ali, A., Arif, W. P., \& Prayitno, T. A. (2019). HOTS-AEP: Higher order thinking skills from elementary to master students in environmental learning. European Journal of Educational Research, 8(4), 935-942.

https://doi.org/10.12973/eujer.8.4.935

Ichsan, I. Z., Sigit, D. V., Miarsyah, M., Ali, A., Suwandi, T., \& Titin, T. (2020). Implementation supplementary book of green consumerism: improving students hots in environmental learning. European Journal of Educational Research, 9(1), 227-237. https://doi.org/10.12973/eujer.9.1.227 
Biosfer, 11 (2) (2020) 87 - 100

Rita Istiana, Oding Sunardi, Fachrine Herlani, Ilmi Zajuli Ichsan, Danilo V. Rogayan Jr., Md. Mehadi Rahman, Mashudi Alamsyah, Giry Marhento, Ahmad Ali, Wiwin Pramita Arif

Janmaimool, P., \& Khajohnmanee, S. (2018). Enhancing university students' global citizenship, public mindedness, and moral quotient for promoting sense of environmental responsibility and proenvironmental behaviours. Environment, Development and Sustainability, $\quad 0123456789$. https://doi.org/10.1007/s10668-0180228-6

Juniarti, Y. (2015). Peningkatan Kecerdasan Naturalis Melalui Metode Kunjungan Lapangan (Field Trip). Jurnal Pendidikan Anak Usia Dini, 9(2), 267284.

Keles, R. (2012). The Quality of Life and the Environment. Procedia - Social and Behavioral Sciences, 35, 23-32.

Leong, S. S. M., Mohd Said, H., Shahrill, M., \& Perera, J. S. H. Q. (2016). Using lesson study to enhance meaningful understanding on the topic of pressure. International Journal of Environmental and Science Education, 11(15), 84258435.

Mauladin, D. (2013). The Effects of Learning Methods and Environmental Knowledge on Age 5-6 Naturalistic Intelligence ( Experiment at AR - Ridho Nature Kindergaten Group B Tembalang Semarang ). Asia Pacific Journal of Multidisciplinary Research, 1(1), 75-88.

McLean, K., Edwards, S., \& Morris, H. (2017). Community playgroup social media and parental learning about young children's play. Computers and Education, 115, 201-210. https://doi.org/10.1016/j.compedu.20 17.08.004

Miarsyah, M., Rusdi, R., Aryani, N. D., \& Ichsan, I. Z. (2019). MEBA: Development android-based ecosystem module for senior high school students. Indian Journal of Public Health Research and Development, 10(8), 2114-2118. https://doi.org/10.5958/09765506.2019.02168.5

Moghavvemi, S., Sulaiman, A., Jaafar, N. I., \& Kasem, N. (2018). Social media as a complementary learning tool for teaching and learning: The case of youtube. International Journal of Management Education, 16(1), 37-42. https://doi.org/10.1016/j.ijme.2017.12 .001

Nugraini, S. H., Choo, K. A., Hin, H. S., \& Hoon, T. S. (2013). Students' feedback of e-av biology website and the learning impact towards biology. Procedia - Social and Behavioral Sciences, 103, 860-869. https://doi.org/10.1016/j.sbspro.2013. 10.408

Oluyinka, O. (2011). Attitude Towards Littering as A Mediator of The Relationship Between Personality Attributes and Responsible Environmental Behavior. Waste Management, 31(12), 2601-2611. https://doi.org/10.1016/j.wasman.201 1.08.014

Puech, C., Dougal, J., Deery, C., Waddell, C., \& Mõttus, R. (2019). Openness Is Related to Proenvironmental Behavior Both Within and Across Families. Environment and Behavior, 1-16. https://doi.org/10.1177/00139165198 53294

Purwanto, A., Ichsan, I. Z., Gomes, P. W. P., Rahman, M. M., \& Irwandani, I. (2020). ESBOR during COVID-19: Analysis students attitude for develop 21st century environmental learning. Journal of Sustainability Science and Management, $\quad$ 15(7), 20-29. https://doi.org/10.46754/jssm.2020.1 0.003 
Biosfer, 11 (2) (2020) 87 - 100

Rita Istiana, Oding Sunardi, Fachrine Herlani, Ilmi Zajuli Ichsan, Danilo V. Rogayan Jr., Md. Mehadi Rahman, Mashudi Alamsyah, Giry Marhento, Ahmad Ali, Wiwin Pramita Arif

Qian, C., Yu, K., \& Gao, J. (2019). Understanding Environmental Attitude and Willingness to Pay With an Objective Measure of Attitude Strength. Environment and Behavior, 1-32. https://doi.org/10.1177/00139165198 55140

Rahman, M. M. (2018). Exploring Teachers Practices of Classroom Assessment in Secondary Science Classes in Bangladesh. Journal of Education and Learning, $\quad 7(4), \quad 274-283$. https://doi.org/10.5539/jel.v7n4p274

Rahmayanti, H., Ichsan, I. Z., Azwar, S. A., Purwandari, D. A., Pertiwi, N., Singh, C. K. S., \& Gomes, P. W. P. (2020). DIFMOL: Indonesian students' Hots and environmental education model during COVID-19. Journal of Sustainability Science and Management, 15(7), 10-19. https://doi.org/10.46754/jssm.2020.1 0.002

Reyna, J., Hanham, J., \& Meier, P. (2018). The Internet explosion, digital media principles and implications to communicate effectively in the digital space. E-Learning and Digital Media, 15(1), 36-52. https://doi.org/10.1177/20427530187 54361

Rogayan Jr, D. V. (2019). I Heart Nature: Perspectives of University Students on Environmental Stewardship. International Journal of Engineering, Science, and Technology, 1(1), 10-16.

Rogayan Jr, D. V, \& Nebrida, E. E. D. (2019). Environmental Awareness and Practices of Science Students: Input for Ecological Management Plan. International Electronic Journal of Environmental Education, 9(2), 106119.
Samsudin, M. A., Haniza, N. H., Abdul-Talib, C., \& Mhd Ibrahim, H. M. (2015). The Relationship between Multiple Intelligences with Preferred Science Teaching and Science Process Skills. Journal of Education and Learning (EduLearn), $9(1), \quad 53$. https://doi.org/10.11591/edulearn.v9i 1.1118

Saputri, A. C., Sajidan, S., Rinanto, Y., Afandi, A., \& Prasetyanti, N. M. (2019). Improving students' critical thinking skills in cell-metabolism learning using stimulating higher order thinking skills model. International Journal of Instruction, 12(1), 327-342. https://doi.org/10.29333/iji.2019.121 $22 \mathrm{a}$

Saputro, A. D., Irwanto, Sri Atun, \& Wilujeng, I. (2019). The impact of problem solving instruction on academic achievement and science process skills among prospective elementary teachers. Elementary Education Online, 18(2), 496-507. https://doi.org/10.17051/ilkonline.20 19.561896

Shabani, N., Ashoori, M., Taghinejad, M., \& Beyrami, H. (2013). The study of green consumers ' characteristics and available green sectors in the market. International Research Journal of Applied and Basic Sciences, 4(7), 18801883.

Sigit, D. V., Miarsyah, M., Komala, R., Suryanda, A., Fadrikal, R., \& Ichsan, I. Z. (2019). Improvement of knowledge and attitude in conservation of mangrove and coral reefs through environmental education community network model. Journal of Physics: Conference Series, 1317(1), 012201. https://doi.org/10.1088/17426596/1317/1/012201 
Biosfer, 11 (2) (2020) 87 - 100

Rita Istiana, Oding Sunardi, Fachrine Herlani, Ilmi Zajuli Ichsan, Danilo V. Rogayan Jr., Md. Mehadi Rahman, Mashudi Alamsyah, Giry Marhento, Ahmad Ali, Wiwin Pramita Arif

Sigit, D. V., Miarsyah, M., Komala, R., Suryanda, A., Ichsan, I. Z., \& Fadrikal, R. (2020). EECN: Analysis, potency, benefit for students knowledge and attitude to conserve mangroves and coral reefs. International Journal of Instruction, 13(1), 125-138. https://doi.org/10.29333/iji.2020.131 $8 \mathrm{a}$

Siriwardena, M., Malalgoda, C., Thayaparan, M., Amaratunga, D., \& Keraminiyage, K. (2013). Disaster resilient built environment: role of lifelong learning and the implications for higher education. International Journal of Strategic Property Management, 17(2), 174-187.

https://doi.org/10.3846/1648715X.20 13.806373

Smith, T. (2014). Elementary Science Instruction: Examining a Virtual Environment for Evidence of Learning, Engagement, and 21st Century Competencies. Education Sciences, 4(1), 122-138.

https://doi.org/10.3390/educsci40101 22

Su, L., Hsu, M. K., \& Boostrom, R. E. (2018). From recreation to responsibility: Increasing environmentally responsible behavior in tourism. Journal of Business Research, April 2018, 0-1. https://doi.org/10.1016/j.jbusres.2018 .12 .055

Sugandini, D., Rahatmawati, I., \& Arundati, R. (2018). Environmental Attitude on the Adoption Decision Mangrove
Conservation: An Empirical Study on Communities in Special Region of Yogyakarta , Indonesia. Review of Integrative Business and Economics Research, 7(1), 266-275.

Takahashi, B., \& Selfa, T. (2015). Predictors of Pro-Environmental Behavior in Rural American Communities. Environment and Behavior, 47(8), 856-876. https://doi.org/10.1177/00139165145 21208

Thapa, B. (2010). The Mediation Effect of Outdoor Recreation Participation on Environmental Attitude-Behavior Correspondence The Mediation Effect of Outdoor Recreation Participation on Environmental Attitude-Behavior Correspondence. The Journal of Environmental Education, 41(3), 133150.

https://doi.org/10.1080/00958960903 439989

Veselinovska, S. S., Gudeva, L. K., \& Djokic, M. (2011). The effect of teaching methods on cognitive achievement in biology studying. Procedia - Social and Behavioral Sciences, 15, 2521-2527. https://doi.org/10.1016/j.sbspro.2011. 04.138

Wahyuni, A., Sulaiman, \& Mahmud, H. (2016). Hubungan Kecerdasan Interpersonal Siswa dengan Perilaku Verbal Bullying di SD Negeri 40 Bandar Aceh. Jurnal Pesona Dasar, 3(4), 34-42. 